\title{
On the Function of National Music in the Development of National Culture
}

\author{
Yi Ji \\ Music and Dance Institute \\ Qujing Normal University \\ Qujing, China
}

\begin{abstract}
The Chinese national music is deeply rooted in national culture as an important part of Chinese traditional national culture and it is an important manifestation pattern of national culture, profoundly reflecting the cultural characteristics and local customs \& practices of different areas and nations. In the new era, as a great strength of national culture propagation, the national music will strengthen culture propagation and communication, intermingling with each other, depending on each other as well as helping each other forward.
\end{abstract}

Keywords-national music; national culture; relationship analysis

\section{NATiOnAl Music AND CULture OVER VIEW}

Music, as the treasure of culture, is deeply rooted in the fertile ground of culture, intermingling with each other, depending on each other and helping each other forward. The music and culture are indivisible that culture cannot spread without music while the further development of music is based on culture, even if the national culture and national music are no exception. The national music and national culture play a significant role in the nation's development and the discussion on the relationship between national culture and national music has important value and practical significance as well. This article is allusion to the relationship between national culture and national music; hence, it is important to define the concept connotation of both. With the wheels of history rolling forward and the continuous development of human civilization, the connotation of culture as well as its components is charging, the national culture and music form their own features in the diversify development.

\section{A. National Music}

There are two meanings in the concept of national music: by the narrowed meaning, it refers to music spreading in minorities, with respect to music of central China is not included because the nation is regarded as minority in that meaning. While by the broader meaning, it refers to the overall grasp and research of music of the whole Chinese nation, which is from a higher and more comprehensive perspective to discuss Chinese traditional music. It is required to maintain its integrality and wholeness in case of research on the relationship between the national music and national culture, digging out the deep-rooted relationship between national music and national culture. What this article discusses is the music of the broader meaning, which has had a far-reaching effect on the past and present as the symbol of Chinese nation.

The national music has a rather long developing history in our country, the rudiment of which emerged over seven thousand years ago and through the subsequent development, its contents become abundant, evolving different regional features. The national music can be divided into south and north classifications by geographical area, of which the southern music is elegant and unrestrained as well as fresh and natural while the northern music is forceful and unsophisticated as well as vast and majestic. From the "mountain song is just like the water of Spring River" of Guangxi to the "Eighteen curve of hill path" of Hubei, then to the "bridge river home" of small towns in Jiangsu and Zhejiang Provinces, the above songs shows that the mild climate and fertile soil of south form the fresh and refined debutante-type southern music while from the sonorous and simple northeast Yangge and song-and-dance duet to vigorous and vast grasslands folk songs and the melodious melody of morinhuur to desolate and magnificent North Shaanxi folk song to the cheerful and active Xinjiang song-dance, then to mysterious and solemn Tibetan longs, the criss-cross plateau and cold weather features of north form the sonorous and plain of northern music. The national music in our country with different characteristics is abundant and diversiform.

\section{B. National Culture}

The national culture refers to what is generated or created during the long-term production and living practice of the nation in common, not only can reflect the material wealth of national features but also reflect the spiritual wealth of national characteristic. Of which diet, clothing, house and means of production belong to material culture; while the languages, words, literature, science, art, philosophy, religion, custom, festival and tradition belong to the spiritual culture. Corresponding to the national music concept, it refers to Chinese traditional national vulture.

The traditional national culture, which is the spirit core and survival foundation of the nation, plays an important role in the nation's development. The Chinese traditional culture is longstanding and well established for thousands of years with great ease. The Chinese traditional national culture occupies an important position in the world culture history and it is rare in the history of world culture that it has inherited for thousands 
of years without fading. The national culture in our country is diversiform covering various aspects of people's life. Chinese traditional national culture has different characteristics in different stages during historical evolution.

\section{ANALYSIS ON THE RELATIONSHIP BETWEEN NATIONAL Music AND NATIONAL CULTURE}

The national music and national culture mingle with each other and help each other forward. This article analyzes the relationship between the two based on the following four points to further explain the above viewpoints:

\section{A. National Music Is the Significant Symbol of the Development of National Culture}

First, music can reflect the historical civilization of a certain region or nation. Such as Xian's "Ancient music", Shanxi's "Eight sets", Fujian's "Nan-yin music", Hebei's "Sheng-wind music" and Jiangnan's "Si-zhu music" etc., which not only have the extant ancient music score but also mutually inherited by generations of musicians. There is a large number of endemic popular music expressing strong regionalism, closely mixed with local historical culture and living habits. From which we can catch a glimpse of the prosperity they have experienced and unaltered splendor position in modern culture during the development of times, in particularly the plectrum used in lute's performance mode and strumming of Fujian's "Nan-yin music" still remains the Tang dynasty style, even the "clappers" and its performance mode used in "Nan-yin music" is almost identical with the musicplayer drawing of Dunhuang murals, hence, it is known as a piece of "music living fossil" by the music industry. Also, the "Nanzhao ancient music" of Yunan Dali autonomous prefecture has a over 1000-year history, by the view of the subsistent representation of which it is not only plain and elegant but also sweet and agreeable, having primitive remaining style mixed with modern factors, enriches the connotation of the national music. At the same time the region enriches the form and content of the culture by mixing and connecting with the culture among different regions and nations. Music is the significant way and forceful mode of nation cultural inheritance.

\section{B. National Music Is the Important Representation of National Culture}

Music can give full expression to the culture characteristics of a nation or region. The music's manifestation of a nation or region is just a wonderful picture scroll in front of our face, making us enjoying their folk conventions, local customs, practices and mental outlook wantonly. There are amounts of nations in our country of which there are many minorities have their own culture feathers and it greatly enriches the connotation of the national music and national culture by combing songs and dances. A variety of nations express their own culture by folk song and dance form, since most of them are coming from the bottom, the expression may seem simple and unadorned at the performance mode, however it highlights the life own tension and tenacious, showing the endless inheriting spirit of national culture.
Hence, these kinds of performances are easy to be accepted and inherited by local populaces. The love songs of minority is also a beautiful landscape in national music and the most of folk music is created by laboring people themselves in life, which can reflect features of local custom and the popularity as well as easily learned features of the folk make it be widespread. The Yunan Dali that an amorous place, much more people due to the movie of Heartlands know it. However, the "Bai nationality tone" of its Jianchuan region is used for the amorous men and women to express their feelings, which is profound \& lyric and gives people keen enjoyment. That song Beside Butterfly Spring singed in Bai nationality tone in the movie Five Golden Flowers have been commonly known by audiences in early time. Hence, the love songs that are once popular within minorities are sung out in the vast motherland and among various nations. The national music accelerates the culture communication and fusion among different nations, playing a great auxo-action to unite people of all nationalities.

\section{National Music Is in Favor of the Protection and Inheritance of Nation Culture}

National music is in favor of the protection and inheritance of national culture. The national music being a kind of spiritual culture is in comparison with the material culture is more longterm and indestructible and it will not disappear with the development of time. The national culture expressed in the national music will get inheritance and protection with the spread of music. The national music faces a wider public with a unique advantage in the inheritance of national culture. Music, which is prone to spread without need of text, has a lower requirement on the culture level of propagative objects, hence, it never interrupts on the spread of national music and the spread of which becomes more extensive.

National music breaks the languages boundary to some degree, since language is not necessary for music to express sometimes, it can utilize the interpersonal empathy ability well to realize the transmission of culture through various alterations of music's rhythm and tone, a verity of feelings and culture are expressed. The national music is active and diversiform and people are prone to internalize the things in daily life into the music to communicate by it, the folk songs of Sichuan, Guangxi, Hunan and other regions are created by laboring people during long-term life, reflecting people's life and local culture. In addition, in the Border Town written by Shen Congwen, the eldest Tian Bao adopts singing folk songs mode to duel with the second Nuo Song for his loved Cui Cui. The national music featuring suiting both refined and popular tastes and all ages has inestimable value to the protection and inheritance of national culture.

\section{National Music Is in Favor of the External Exchange and Propagation of National Culture}

Music is language without borders. It breaks the language barrier to conduct further communication and exchange among different culture. From the Chinese classical music to western classical music, a variety of music has no language that people feel the culture behind the music by perceiving it. The singer Wang Lihong, acting as the cultural propaganda ambassador, mentioned in his lecture at Oxford that, music is the best tool 
to know the culture of a country, also he mentioned music is favor of eliminating the interpersonal prejudice and barrier and become the bridge of culture exchange among different nations or even different countries. In recent years, more and more foreign friends become interested in Peking opera and a series of music with extreme national features and Peking opera plays a more and more important role for spreading Chinese culture as a symbol of national culture all over the world. At the same time, with the fiery performance of music talent show emerging, the bands with extreme national features, such as Mountain Man Music Band, is appreciated by global music lovers and holds amount of vocal concerts successfully; moreover, the HAYA band of Qinghai lakeside is composed of members from different nations and countries per se, it is music that makes them cross the language barrier and achieve the fusion of music culture. All these advertise the national music in our country commendably, playing culture exchange function.

\section{CARRY FORWARD NATIONAL MUSIC AND STRENGTHEN CULTURE DIVERSITY CONSTRUCTION}

It emphatically analyzes the relationship between national music and national culture in the above content that national music plays a key function to the culture inheritance as an important part of national culture. Nevertheless, in the fickle new era, confronting the challenges in the new era, national music should strengthen the main body function of national culture. However, the cultural diversity is a key to guarantee the standing room of national culture. Only the music culture featuring various national unique characteristics is enduring, it will enrich the national culture in our country much more and remain the diversity and independency of national culture, so as to realize "the Chinese Dream" early and implement the great rejuvenation of Chinese nation.

In the new era, how we can inherit national music preferably and make it play a greater function in the national development is a question to us as well as a test for us. In allusion to how we can carry forward national music and strengthen cultural diversity, some of my own advices are given in following:

\section{A. Fuse the Traditional Music with Modern Factors}

The traditional national music has been a part of our life during the constantly development and improvement. However, due to the continuous speed-up process of modernization, the traditional national music is impacted in the fierce competition of culture market. However, in order to remain the freshness of traditional culture, it is required to fuse it with modernization factors. The current TV media, mobile phone media, network media and other new media occupy an increasingly ratio in people's life and they are favored and admired by the universality and swiftness of propagation. While there are many activities taken national music as theme in related talent shows, which provide favorable platform and windows for people to know more about national music. In addition, TV media and network media etc. new medium provides a good opportunity for national music to perform their charm as well as it can move more people by showing their performance on the media platform. In order to remain the freshness of culture, it is required to advance with times.

\section{B. Reveal National Music by Multi-path}

The main paths to contact national music in people's life are: family education, the inheritance of national music per se; school education, spreads national music from a higher and more scientific aspect; network environment, the most widely propagation path with largest amount of information; international influence, the favorable platform for people to know their culture and international culture. From above we can see that there are many ways for people to contact national music in their life and it is necessary to conduct efficient propagation of national music by various paths, moreover, the construction of cultural diversity is of great significance. It can fuse further national music modes into family education, carrying out education on the next generation by some traditional national music instead of other education forms. With respect to school education, it can conduct reprocessing and recreation on national music by combining local custom features, injecting new vitality to the national music. Provide more communication platform on the network for national music, encourage the propagation of national music as well as perform more and more national music at the international exchange and national stage.

\section{Openness and Inclusiveness, Absorb Various Culture}

"Why the canal is so clean, since it has running water injected", only the national culture and national music communicate with other music and culture can they constantly enrich their own connotation and forms, realizing the cultural diversity construction. Due to the complexity of global culture, it is required to absorb and receive the new culture with a prudent and critical attitude, to not only remain independency per se but also absorb new things. At last, for remaining the diversity of national culture, it should be based on national music to realize the propagation and development of national culture through various forms of music propagation. The construction of national music is a long-term process and a big project on time and space, requiring constant inheritance. It needs the extensive mass base while the popularity and diversity of national music provide favorable soil for the propagation of national culture. Organically integrate the propagation of national music and construction of cultural diversity to realize the better and wider propagation of national culture by the facilitation function between each other.

\section{CONCLUSION}

National music, as an important part of national culture, plays an irreplaceable role in the inheritance of traditional culture in our country. It is the miniature of the development of Chinese national traditional culture, embodying the abundant cultural deposits and unique spiritual connotation of our country. However, in the new era, we must sparkplug our national culture to be stronger and better which depends on the constant development and promotion of national music. In conclusion, only with the understanding, inheritance and protection of Chinese national music can we inherit the national culture and artistic spirit of our country preferably, 
moreover, only correctly grasp the relationship between Chinese national music and national culture can we actually understand the Chinese cultural spirit.

\section{REFERENCES}

[1] Li Ling. Simple Analysis on the Relationship between Music and Culture Development [J]. Journal of Yunan Arts. 2004(2).

[2] Zhou Hui. Discussion on the Relationship between Music and Cultural Life [J]. Education Science \& Culture Magazine. 2008(5)

[3] Liu Haiyan. Brief Discussion on National Music and Chinese Traditional Culture [J]. Journal of Liaocheng University. 2008 (02)

[4] Xian Jing. Brief Discussion on the Relationship between Music and Culture. $[\mathrm{J}]$. Journal of Ji Ningnan Normal Specialised Postsecondary College. 2006 (04).

[5] Fan Lizhi. Inheritance of School Misic Education and National Music Culture $[\mathrm{J}]$. Journal of Northwest University (Philosophy and social sciences ed), 2005,06:142-145.

[6] Guo Degang. Discussion on Minority Music Culture Inheritance and Inner Mongolia College Music Education [J]. Music of China, 2010,01:261-266.

[7] Yang Minkang. Study on the Historical Development and Tendency of Two-way Viewing-angle Cultural Position of National Music (next) [J]. Art of Music. Journal of Shanghai Conservatory of Music. 2004,02:52$59+4$.

[8] Wang Li. Applied Research on Chinese Minority Music in Sightsinging Teaching under the Culture Prosperity Background [D]. Northeast Normal University. 2013.

[9] Wang Ying. The Inheritance and Development of National Music under the Multi-culture Background [J]. the Grand Stage. 2013,03:241-242.

[10] Dou Junhong. the National Music under the Value of Cultural Relativism Music. [J]. Popular Literature (Theory) 2009,12:78-79.

[11] Dong Xiaoping. the Subjectivity of National Music and National Culture [J]. Journal of Xinghai Conservatory of Music. 2015,01:1-4+37. 